\title{
'Fine words, but few deeds' in Clinton science statement
}

Washington. The Clinton administration is expected to publish a broad-ranging policy statement within the next few weeks, setting out the reasons for its support for basic science, and suggesting ways in which this support could be made more effective.

This follows last week's approval of the planned statement, being referred to as a white paper, at the first meeting of the $\mathrm{Na}$ tional Science and Technology Council (NSTC), a new body created by President Bill Clinton last year to co-ordinate US science policy. The statement is expected to put forward various broad recommendations for government policy, emphasizing, for example, the need for government agencies to share the costs of new research laboratories and equipment.

But officials who have seen the document say that it avoids outlining research priorities, and contains few figures or directives for agencies (such as how cost-sharing could be required of them in practice). Nor does it deal with burning issues such as the congressional threat to cut funding for defence research in the universities (see Nature 369, 694; 1994).

As a result, the proposed statement is already causing scepticism in Congress. "There's a lot of philosophy in it, but no specifics," complains one staff director.

Nevertheless John Gibbons, thepresident's science adviser, said after the meeting on 29 June that unanimous endorsement of the statement was a "very positive start" for NSTC, and had "allowed the president to express his support for science and technology".

Preparation of the white paper was set in motion at the beginning of the year by the fundamental science subcommittee of NSTC, a cabinet-level body intended to oversee US science and technology programmes which this year will cost $\$ 72$ billion, one-seventh of the entire discretionary budget of the US government (Nature 366, 393; 1993).

A statement issued by the White House after last week's meeting said that Clinton told the cabinet ministers and agency heads who attended "to continue to work to reprioritize science and technology investments to match national goals".

The president added that other goals for the NSTC - most of whose work is done by its nine subcommittees, with the council itself expected to meet only rarely - were to forge better links with industry, to persuade the general public of the value of science, and to expand international science and technology co-operation.

According to some accounts, Vice-President $\mathrm{Al}$ Gore, who took over as chairman when Clinton left 30 minutes into the 80 - minute meeting, lived up to his reputation as a technophile by telling the group to share ideas about one of his pet projects, the "information superhighway".

Donna Shalala, the secretary of health, and Neal Lane, the director of the National Science Foundation, each took the opportunity to emphasize to Clinton the value of fundamental science. Shalala pointed out the economic as well as social benefits of biomedical research, while Lane referred to the need to build closer links between research and teaching in universities.

Others present at the closed meeting included Hazel O'Leary, the secretary of energy, Richard Riley, the secretary of education, Federico Peña, the secretary of transportation, deputy defence secretary John Deutch, Dan Goldin, administrator of the National Aeronautics and Space Administration, and Carol Browner, administrator of the Environmental Protection Agency.

Also in attendance were Leon Panetta, newly appointed White House chief of staff, Alice Rivlin, his successor at the Office of Management and Budget, James Woolsey, head of the Central Intelligence Agency, and Laura Tyson, the president's economics adviser. Harold Varmus, the director of National Institutes of Health, having fought successfully for a seat on the council, was on holiday, and was represented by his deputy, Ruth Kirschstein.

Apart from the white paper, which most people in the room had already approved, the meeting endorsed the need to enable and encourage more minorities and women to enter scientific careers, and for agencies and departments to work more closely together.

The science white paper was originally drafted for the White House by the head of physics at the Massachusetts Institute of Technology, Ernest Moniz. According to officials who have read it, the statement is said to be considerably less specific than a corresponding document on technology produced last year.

One congressional staff member says that the original draft has experienced "homogenization" at the request of different interested agencies so that "it ends up just pontificating, which is not what we need; we get enough of that already".

Defenders of the white paper say that it has fulfilled its main task, namely explaining why the government should continue to invest in fundamental science. But, as one official acknowledges: "People expecting it to propose a whole new way of doing business will perhaps be disappointed." There is, after all, no broad consensus that American science is broken - let alone on how to fix it if it is.

Colin Macilwain

\section{LHC's backers in Congress prepare to take on critics}

Washington. Leading members of the House of Representatives' science, space and technology committee have put forward a bill backing the involvement of the United States in the construction of Europe's planned Large Hadron Collider (LHC).

The bill endorses budgets for highenergy physics at the level proposed in May by an advisory panel chaired by Sidney Drell of the Stanford Linear Accelerator Center (see Nature 369, 266; 1994). The panel said that physics needed an extra $\$ 150$ million over the three years from 1996 to allow the United States to fund its domestic programme, while providing initial support for the LHC.

The high-energy physics bill also directs Hazel O'Leary, the secretary of energy, to negotiate with the European Laboratory for Particle Physics (CERN) on US involvement in planning and construction of LHC.

But it also sets conditions on any resultant agreement, including a fixed ceiling on the US contribution and provision for US

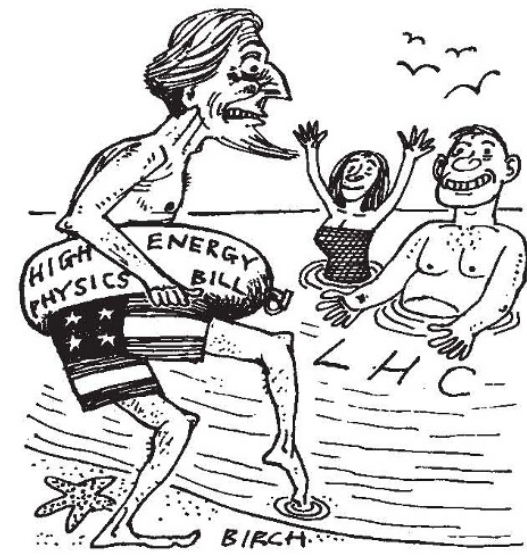

withdrawal if benchmarks are not met.

Introducing the bill, committee chairman George Brown said that a successful experience in international collaboration at CERN was needed "to change the impression that the United States is not a reliable international partner" in big science projects.

The bill is also sponsored by science subcommittee chairman Rick Boucher (Democrat, Virginia) and by Sherwood Boehlert (Republican, New York), both of whom played a key role in halting the Superconducting Super Collider last summer.

The bill is by no means certain to pass the House. And even if it does, it would not guarantee US funding for $\mathrm{LHC}$, as this is set annually in the Congressional budget. But its introduction indicates solid Congressional support for the LHC, ready to take on detractors who argue that, as there was no European support for SSC, there should be no US support for CERN.

C. $M$. 